\title{
Deleterious Effects of Storage Environmental Conditions on The Seed Quality of Two Varieties of Tomato (Solanum lycopersicum L.) Stored in Triple Laminated Aluminum Packing in Sri Lanka
}

\author{
R.A.I.S. Ariyarathna*, S.L. Weerasena, C.K. Beneragama
}

Post Graduate Institute of Agriculture, University of Peradeniya, Peradeniya, Sri Lanka

Article Information
Received: 15 November 2020
Revised version received: 18 December 2020
Accepted: 21 December 2020
Published: 28 December 2020
Cite this article as:
R.A.I.S. Ariyarathna et al. (2020) Int. J. Appl. Sci.
Biotechnol. Vol $8(4): 437-447$.
DOI: $10.3126 /$ ijasbt.v8i4.33670
*Corresponding author
R.A.I.S. Ariyarathna,
Post Graduate Institute of Agriculture, University of
Peradeniya, Peradeniya, Sri Lanka
Email: indira.ariyarathna @ gmail.com
Peer reviewed under authority of IJASBT
(C) 2020 International Journal of Applied Sciences and
Biotechnology
This is an open access article \& it is licensed under a Creative
(https://creativecommons.org/licenses/by-nc/4.0/)
OP EN

\section{Article Information}

Accepted: 21 December 2020

Published: 28 December 2020

Cite this article as:

Biotechnol. Vol 8(4): 437-447.

DOI: $\underline{10.3126 / \text { ijasbt.v8i4.33670 }}$

*Corresponding author

Ariyarathna,

Post Graduate Institute of Agriculture, University of Peradeniya, Peradeniya, Sri Lanka

Peer reviewed under authority of IJASBT

(C) 2020 International Journal of Applied Sciences and Biotechnology

Keywords: Field emergence; Environmental effects; seed health; seed quality parameters; seed storage; TLA

\begin{abstract}
Tomato is one of the most commonly growing vegetable crops among the farmers in Sri Lanka. Standard laboratory germination of tomato seeds fulfills the regulatory requirements of seed marketing. However, poor field performance is an overwhelming problem to farmers. Present study was focused on the longevity of two varieties of tomato seeds as affected by their quality characters (percentage germination, moisture, field emergence and vigour index, seed protein and carbohydrate contents) including seed health (exposure of Clavibacter michiganensis subsp. Michiganensis (CMMV), Spotted wilt virus (TSWV) and Leaf curly top virus (LCTV)) under four different storage environmental conditions during a one-year long storage study. Seeds were packed in triple-laminated aluminum packets (TLA) and stored in low temperature storage conditions $\left(17 \pm 1{ }^{\circ} \mathrm{C}\right.$ and $\left.65 \% \mathrm{RH}\right)$ and in ambient conditions in Gannoruwa, Kundasale, and MahaIlluppallama that represent the three agro-ecologically zones; Mid Country Wet Zone (MCWZ), Mid Country Intermediate Zone (MCIZ) and Low Country Dry Zone (LCDZ) respectively. Seed quality parameters displayed varied responses depending on the variety. Physiological changes that occur in seeds due to temperature, RH, changes in proteins and carbohydrate content, CMMV and TSWV during storage were manifested as reduction in seed germination, field emergence and vigour index. However, none of the seedling carried LCTV and therefore its effect on seed quality parameters could not be assessed. The seeds could be stored for $c a .29$ months at low and constant temperatures and RH conditions without compromising local seed germination standards compared to ambient storage in the three environments. CMMV and TSWV detected in all seed samples indicated potential threats to tomato farmers in Sri Lanka.
\end{abstract}

\section{Introduction}

Provision of good quality seeds to farmers at the right time has a direct impact on crop production targeting food security (FAO, 2016). Seeds as the basic input of agriculture must possess good germinability and successful field emergence, leading to proper stand establishment which would indicate profitable potential yields. Seeds pass through several well-defined sequential agronomic steps from sowing to harvest with required inputs in the field. In addition to pre-harvest operations, post-harvest operations such as timely harvesting, seed processing, careful transportation, storage and handling need extra attention. 
Seeds at each stage of this long chain are vulnerable to biotic and abiotic stresses (Maity et al., 2013).

Germination percentage of seeds under laboratory conditions is highly satisfactory and ensures the seed certification standards. However, farmers throughout the country complain their low level of field performances. This situation is detrimental to the reputation of the Department of Agriculture (DOA) in Sri Lanka as it can impair the reliability of seeds marketed as "certified". Having gone through the rigorous certification process, the only possibility for these complaints is that, there may be some adverse packing, storage or environmental condition on the quality of the seeds. Several studies have shown that storage condition is the foremost factor in determining the longevity and stability of many seeds (Adsul et al., 2018; Ariyarathna et al, 2020; Ariyarathna et al., 2020a; Copeland and McDonald, 1995; Sano et al., 2016; Pradhan et al., 2012; Shelar et al., 2008).

Generally, certified seeds are stored until retail in different regions of the country. Elevation is the main cause of regional changes in air temperature in Sri Lanka. The mean monthly temperature varies slightly depending on the seasonal movements of the sun under the impact of variations caused by rainfall. Diurnal variation of the temperature is characterized by reaching the maximum early in the afternoon and the minimum shortly before dawn. Relative humidity (RH) varies generally from about $70 \%$ during the day to about $90-95 \%$ at night. These values are lower in the dry zone by about five percent while in the driest areas in North-West and South-East, RH drops to about $60 \%$ (Statistical Abstract, 2018). Given the environmental diversity of the country and locations of seed production, processing and marketing, the seed lots could be adversely exposed to climatic fluctuations.

Tomato (Solanum lycopersicum L.) is considered a tropical vegetable and is one of the most widely consumed vegetables in the world due to its high nutritional value (Ferrari et al., 2008; Bergougnoux, 2014) and is used fresh and in processed forms (Arrieta-Baez et al., 2015). It is the second largest production of vegetable in the world after potatoes (http://faostat.fao.org) and is cultivated in every area of the world. In Sri Lanka, tomato is a popular vegetable with annual total extent of 5,329 ha with a production of $80,839 \mathrm{mt}$ and an average yield 15.17 tons per ha. (Statistical abstract, 2019). Tomato seeds with certified germination have also been reported as poor in field emergence by the farmers in Sri Lanka. Therefore, this study was focused on explicating the differences in retail storage environments on seed quality parameters including seed health, and to define proper storage environmental conditions for tomato seeds packed in triple laminated aluminum foil. In addition, the study included determination of any variations in seed protein and carbohydrate content during storage and seed health aspects, especially upon contamination by CMMV and TSWV.

\section{Methodology}

Certified seed lots of two tomato (Solanum lycopersicum L.) varieties; Lanka Sour (LS) and Ravi (R) were used for the study. In both LS and $\mathrm{R}$, the initial germination percentage ( $83 \%$ and $89 \%$, respectively) and moisture content $(7.2 \%$ and $7.9 \%$ respectively) were recorded. Seed lots of $1 \mathrm{~kg}$ produced from contracted farmers of the DOA were transported to the seed processing center at Kundasale. Seeds were packed in to $10 \mathrm{~g}$ of small quantities in each of triple laminated aluminum (TLA) foil and kept them at Vegetable Seed Center (DOA) Gannoruwa (Mid Country Wet Zone), Seed Sales Centers of Kundasale (Mid Country Intermediate Zone) and MahaIlluppallama (Low Country Dry Zone) of the DOA, under ambient conditions. In addition, the same amount of retail packets was kept in low temperature condition $\left(17 \pm 1{ }^{\circ} \mathrm{C}\right.$ at $\left.65 \% \mathrm{RH}\right)$ in the cold storage facility of Seed Certification Service, Gannoruwa.

Laboratory and field tests were completed at monthly intervals with three replicates during a one-year storage period at Central Seed Testing Laboratory and Post control field 1 in Gannoruwa, Peradeniya. Temperature and RH of all locations were monitored using thermohygrometers. Daily temperature of maximum and minimum, and relative humidity (RH) values of morning and evening were obtained from the Natural Resources Management Center (NRMC) of DOA.

Agro-climatic zones are distinguished by altitude and rainfall distribution pattern primarily. Mid Country Wet Zone (MCWZ) is characterized by an altitude between 300$900 \mathrm{~m}$ and with an annual rainfall of more than 2,500 $\mathrm{mm}$. Mid Country Intermediate Zone (MCIZ) receives an annual rainfall between 1750 - $2500 \mathrm{~mm}$ with the same altitude as MCWZ while altitude of less than $300 \mathrm{~m}$ with an annual rainfall less than $1750 \mathrm{~mm}$ belongs to the Low Country Dry Zone (LCDZ) (Punyawardhana, 2008).

\section{Estimating Germination, Field Emergence and Vigour Index}

According to the guideline of International Seed Testing Association (2015), germination test was done by using two-hundred seeds for each treatment as $100 \times 2$ on top of paper (TP) method spending on germination chamber at $25 \pm 1{ }^{\circ} \mathrm{C}$ with 8 hours light. Number of germinated seeds was counted on the $7^{\text {th }}$ day of germination as the first count and on the $10^{\text {th }}$ day as the final count. Normal seedling count expressed as a percentage which obtained on the $10^{\text {th }}$ day of the germination of seedlings. Seedling length of randomly selected 40 seedlings was measured on the $7^{\text {th }}$ day of the germination. Seedling vigour index was determined by multiplying the germination percentage and the seedling length as prescribed by Abdul-Baki and Anderson (1973). Field Emergence percentage was determined by grow out 
trial done by monthly intervals at Gannoruwa with Randomized Complete Block Design and three replicates. One hundred seeds per replicate were sown in wellpulverized soil and normal seedlings which emerged after 14th day of the planting were counted and expressed as the percentage of field emergence. Seed moisture content was determined by oven dry method according to ISTA guidelines $\left(130{ }^{\circ} \mathrm{C}\right.$ for one hour).

\section{Determination of Protein and Carbohydrate Content}

The protein content of seeds was assessed by using the Kjeldahl method according to Ranst et al. (1999). Total carbohydrate content was analyzed spectrophotometrically using the Carbohydrates Estimation Teaching Kit (Hiper®) (Solarte et al., 2014). Samples with three replicates were taken once every 3 months for testing of proteins and carbohydrates over a period of one year.

\section{Detection of Bacterial Canker \{Clavibacter michiganensis sub spp michiganensis (CMMV)\}}

One-hundred and fifty seeds of tomato seeds were exterior disinfected with $1 \%$ Sodium hypochlorite and washed thoroughly with deionized water. They were placed on water-soaked germination paper in germination boxes and were allowed to germinate for 7 days. After 7 days, 100 seedlings were taken and ground in SEB4 sample extraction bags using SEB4 sample extraction buffer. Thereafter, the ImmunoStrip [Agdia Cmm ImmunoStrip (product number 44001)] was inserted into the bag until submerged in the extract up to the white line and kept for 30 minutes. Thereafter, the strip was removed and the results were interpreted (Tanina and Kawaguchi, 2011).

\section{Detection of Tomato Spotted Wilt Virus (TSWV) and Leaf Curly Top Virus (LCTV)}

For the detection of TSWV and LCTV, Agdia ELISA kit and ACD's ELISA kit were used respectively. Seven days old 100 seedlings of tomatoes were placed a sterilized polythene bag and ground using a mortar. Ground plant sap was diluted with the general extraction buffer in 1:10 ratio. These seedlings were also planted under the sterilized condition explained above using the ImmunoStrip method.

Samples with three replicates were drawn every 3 months for seed health tests over a period of one year.
The experimental design was Completely Randomized Design (except for the field trial) with three factor factorial (variety $\times$ location $\times$ time) arranged with three replicates. SAS (Windows 9) statistical software was used to analyze data while probit analysis were used to develop seed survival curves of the two varieties of tomato under different environmental storage conditions. (Roberts and Ellis, 1989). Time in months that the seeds remained within the seed certification standards $(75 \%)$ as $\mathrm{p}_{75}$ and $\mathrm{p}_{50}$ as longevity (germination standard $50 \%$ ) were calculated by regression equation.

\section{Results and Discussion}

Table 1 shows the mean annual temperature and relative humidity in different storage conditions during the study period of one year. Of all locations, the highest maximum and minimum mean temperatures were recorded at Mahallluppallama. In addition, the highest morning $\mathrm{RH}$ and the lowest evening $\mathrm{RH}$ values were also recorded at the same location.

\section{Seed Germination}

Seed germination curves fitted by probit analysis of the two varieties of tomato stored at different storage conditions over 12 months are presented in Fig. 1. Germination of seeds of both tomato varieties under constant low temperature $\left(17 \pm 1^{\circ} \mathrm{C}\right)$ with $65 \% \mathrm{RH}$, and under ambient conditions decreased over 12-month period of storage. However, at low temperature seeds of both varieties successfully maintained germination above the norm up to 11 months compared to ambient conditions where germination declined rapidly especially on variety Ravi. The fastest decline in germination was noted in the seeds stored in LCDZ.

Tomato seed germination was significantly affected by storage time, storage conditions and their interaction ( $p$ $<0.0001)$.

In the present study, when seed survival curves of seed lots of variety LS and Ravi were compared under different storage conditions, the time to viability to fall to $75 \%$ of minimum seed certification standard for germination (i.e. $75 \%$, denoted as p75) and longevity as p50 derived from the probit plots of Figure 1, differed considerably (Table 2).

Table 1: Mean annual temperature and relative humidity at the different storage conditions over the study period of one year.

\begin{tabular}{|c|c|c|c|c|c|c|}
\hline \multirow[b]{2}{*}{ Storage Location } & \multicolumn{2}{|c|}{$\begin{array}{c}\text { Mean } \\
\text { Temperature }\left({ }^{\circ} \mathbf{C}\right)\end{array}$} & \multirow{2}{*}{$\begin{array}{l}\text { Mean } \\
\text { difference } \\
\text { between } \\
\text { Max and } \\
\text { Min }\end{array}$} & \multicolumn{2}{|c|}{ Mean RH (\%) } & \multirow{2}{*}{$\begin{array}{l}\text { Mean } \\
\text { difference } \\
\text { between } \\
\text { Morning and } \\
\text { Evening }\end{array}$} \\
\hline & Max & Min & & Morning & Evening & \\
\hline Low Temperature Condition (LT) & $17 \pm 1$ & $17 \pm 1$ & 0 & 65 & 65 & 0 \\
\hline Gannoruwa (MCWZ) & $29.6 \pm 1.2$ & $21.3 \pm 1.6$ & $8.3 \pm 1.8$ & $77.9 \pm 3.1$ & $68.1 \pm 6.1$ & $9.8 \pm 4.0$ \\
\hline Kundasale (LCDZ) & $30.4 \pm 1.3$ & $20.6 \pm 1.6$ & $9.8 \pm 1.6$ & $76.6 \pm 4.8$ & $63.9 \pm 5.8$ & $12.8 \pm 6.2$ \\
\hline MahaIlluppallama (LCDZ) & $32.4 \pm 1.7$ & $23.3 \pm 2.0$ & $9.1 \pm 1.5$ & $83.3 \pm 5.6$ & $60.9 \pm 7.5$ & $22.4 \pm 6.2$ \\
\hline
\end{tabular}



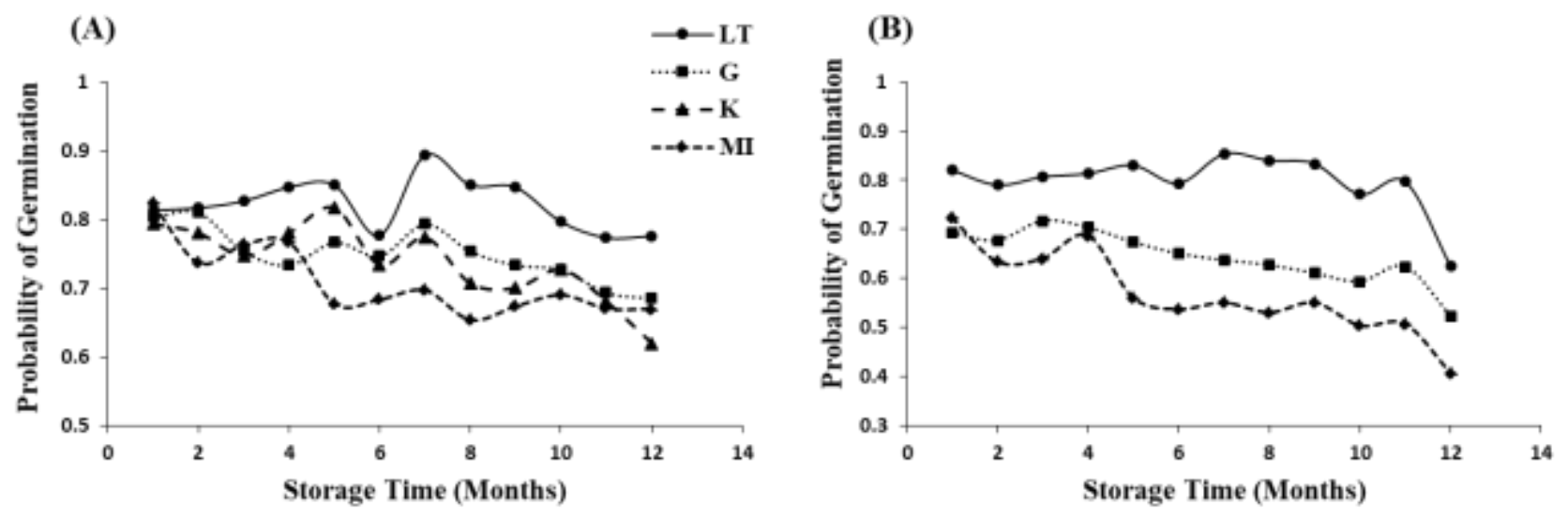

Fig. 1: storage conditions affected on germination of tomato seeds stored in retail packets with time, expressed as the probability of germination fitted by probit analysis (seed survival curves): A) Lanka Sour and B) Ravi. LT-Low temperature condition G-Gannoruwa (MCWZ); K-Kundasale (MCIZ); MI- MahaIlluppallama (LCDZ). Dashed horizontal line shows the 0.75 probability of germination

Table 2: the time to viability to fall to $75 \%$ minimum seed certification standard for germination $(75 \%)\left(\mathrm{p}_{75}\right)$ and $(50 \%)\left(\mathrm{p}_{50}\right)$ derived from the probit plots of Figure 1, under different storage conditions in tomato varieties Lanka Sour and Ravi

\begin{tabular}{|c|c|c|c|c|c|c|c|c|}
\hline \multirow[b]{2}{*}{$\begin{array}{l}\text { Storage } \\
\text { Condition }\end{array}$} & \multicolumn{4}{|l|}{ Lanka Sour } & \multicolumn{4}{|l|}{ Ravi } \\
\hline & $\begin{array}{l}\text { Initial } \\
\text { Germination } \\
(\%)\end{array}$ & $\begin{array}{l}\text { Initial } \\
\text { Moisture } \\
(\%)\end{array}$ & $\begin{array}{l}\mathbf{P}_{75} \\
\text { (months) }\end{array}$ & $\begin{array}{l}\mathbf{P}_{50} \\
\text { (months) }\end{array}$ & $\begin{array}{l}\text { Initial } \\
\text { Germination } \\
(\%)\end{array}$ & $\begin{array}{l}\text { Initial } \\
\text { Moisture } \\
(\%)\end{array}$ & $\begin{array}{l}P_{75} \\
\text { (months) }\end{array}$ & $\begin{array}{l}\mathbf{P}_{50} \\
\text { (months) }\end{array}$ \\
\hline Low & 83 & 7.2 & 29.8 & 110.5 & 89 & 7.9 & 12.9 & 46.2 \\
\hline Temperature & & & & & & & & \\
\hline Gannoruwa & 83 & 7.2 & 6.4 & 34.5 & 89 & 7.9 & -1.4 & 17.2 \\
\hline Kundasale & 83 & 7.2 & 5.5 & 25.3 & - & - & - & - \\
\hline MI & 83 & 7.2 & 2.9 & 24.5 & 89 & 7.9 & -1.6 & 9.6 \\
\hline
\end{tabular}

The drastic decline in germination with time in different storage conditions in variety Ravi was significant although the initial germination and moisture were at acceptable levels. Local seed certification standards of germination and moisture for tomato are $75 \%$ and $9 \%$ respectively (Seed Certification Standards Hand Book, 1983). Further, seeds of variety Ravi maintained germinability slightly above the acceptable level only under low temperature conditions. All samples were subjected to standard dormancy breaking treatments and retested. However, the results were identical (data not shown).

In the present study, there was hardly any chance for the equilibrium moisture content in seeds to fluctuate because the tomato seeds were packed and sealed in triple laminated aluminum foil packets. Water vapor transmission rate and oxygen transmission rate are the utmost important barrier properties of packing material which can affect the shelf life of the product (Dutta and Dutta, 2016). The calculated water vapor transmission rate was $0.2910 \mathrm{~g} / \mathrm{m}^{2} /$ day and oxygen transmission rate was $0.21993 \mathrm{cc} / \mathrm{m}^{2} /$ day in triple laminated aluminium foil (Robertson, 2013). Deterioration of germination with high humidity is related to the hygroscopic nature of the seeds; It is associated with the relative humidity of the ambient air, especially under hot temperatures. Thus, equilibrium moisture content and equilibrium relative humidity are essential to minimize deterioration thereby to maintain a higher longevity (Vertucci \& Roos, 1993).

Seed deterioration in stored seeds is a natural phenomenon. As previously reported, the temperature and relative humidity negatively influences the viability of stored seeds even under ideal storage conditions (Shaban, 2013). Seeds stored under ambient conditions rapidly lose their viability and vigor due to changes in temperature and relative humidity of storage conditions. (Adriana et al., 2012). Similar negative effects on germination were seen in the present study during seed storage under ambient conditions.

\section{Field Emergence}

Field emergence was significantly affected by the storage time and storage condition. There was no significant effect of variety on field emergence. Significant decline compared to laboratory germination was observed in field emergence even after one month of storage in both varieties. (Table 3 ). Field emergence continued to decline over the 12 month period. However, there is no official standard for field emergence percentage for tomato seeds in Sri Lanka although its necessity is apparent. 
Table 3: Storage time and storage condition affected on field emergence of two varieties of tomato.

\begin{tabular}{ccc}
\hline \multirow{2}{*}{ Storage Time (Months) } & \multicolumn{2}{c}{ Field emergence (\%) } \\
\cline { 2 - 3 } & var. LS & var. Ravi \\
\hline 1 & $66.0^{\mathrm{a}}$ & $69.0^{\mathrm{A}}$ \\
2 & $65.0^{\mathrm{a}}$ & $64.5^{\mathrm{B}}$ \\
3 & $61.2^{\mathrm{ab}}$ & $64.2^{\mathrm{B}}$ \\
5 & $58.7 \mathrm{bc}$ & $62.6^{\mathrm{B}}$ \\
6 & $59.1^{\mathrm{bc}}$ & $59.1^{\mathrm{C}}$ \\
7 & $56.4^{\mathrm{bcd}}$ & $59.6^{\mathrm{CD}}$ \\
8 & $56.5^{\mathrm{bcd}}$ & $57.8^{\mathrm{CD}}$ \\
9 & $54.7^{\mathrm{cd}}$ & $55.2^{\mathrm{DE}}$ \\
10 & $54.9^{\mathrm{cd}}$ & $52.7^{\mathrm{EF}}$ \\
11 & $52.3^{\mathrm{d}}$ & $50.8^{\mathrm{FG}}$ \\
12 & $51.0^{\mathrm{de}}$ & $46.4^{\mathrm{G}}$ \\
Storage Condition & $45.6^{\mathrm{e}}$ & $43.0^{\mathrm{G}}$ \\
Low Temperature (LT) & $61.2^{\mathrm{a}}$ & $65.3^{\mathrm{A}}$ \\
Gannoruwa (G) & $55.1^{\mathrm{b}}$ & $53.7^{\mathrm{B}}$ \\
Kundasale (K) & $60.8^{\mathrm{a}}$ & - \\
MahaIlluppallama (MI) & $50.0^{\mathrm{c}}$ & $51.5^{\mathrm{C}}$ \\
\hline CV (\%) & 11.59 & 6.63 \\
\hline Mens & &
\end{tabular}

Means with the same superscript letters within columns are statistically non-significant at $5 \%$ level of probability (DMR test). Note the upper case and lower-case letters for two different varieties to compare between rows

\section{Vigour Index}

In the current study, seedling length at first count was used to minimize the analysis time. Vigour index was affected by storage time, storage condition, variety and the interaction effect of storage time and variety $(\mathrm{p}<0.0001)$ (Figure 2). Seeds stored under low temperature conditions in both varieties had the highest vigour index.

Gannoruwa and Kundasale locations showed the secondbest values of mean vigour index of all ambient storage conditions while MahaIlluppallama had the lowest in seed quality evaluation. As described by Santorum et al., (2013) standard germination does not offer satisfactory indication and thus, vigour considered to be explanation on field emergency after cultivation. Many previous studies have

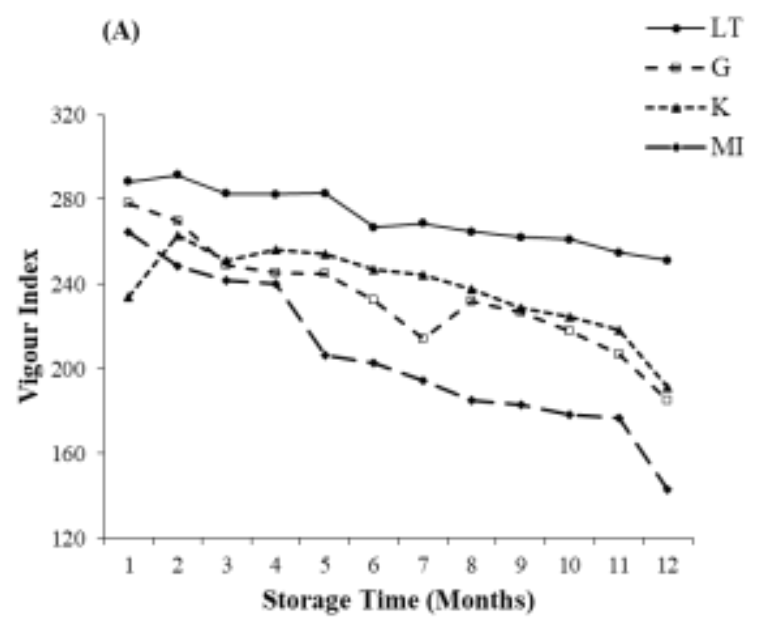

shown that it is sufficient to assess the relationship between quality of seeds and seedlings in a short period of time under laboratory condition without looking beyond 14 days after a sowing in the field (Dutt and Geneve, 2007: Gholami,2009). In 2004, by Oakley et al, seedling length was used to determine the quality of diverse seed lots by means of vigour successfully. A similar quick ranking system for seed lots could be evolved using data from the first count during the test of germination at least for vegetable seeds.

\section{Relationship Between First Count Germination, Final Count Germination, Moisture, Field Emergence and Vigour Index}

The first count in the germination test which was taken at the end of the seventh day after commencement of the germination is an indicator of seed vigour and was more correlated with the field emergence (0.59) (Table 3). Field emergence was more positively correlated with vigour index (0.66) which suggests that high vigour seedlings result in better field performance as always expected.

Physiological quality, especially the vigour of a seed lot is an important consideration during seed production because it could estimate and predict performances of seed in the field. Its storage potential and basic information on seed stock disposal help to reduce risk and loss and improve market competitiveness. Therefore, methods are being developed to quickly and efficiently evaluate the physiological quality of seeds so that decisions can be made on the collection, processing, storage and marketing of seed crops (Barros and Marcos-Filho, 1997; Pinto et al., 2007). The present study suggests the need for assessment of seed vigour during the laboratory germination test as a determinant of the field value of seeds. It would be an important tool in the hands of seed producer organizations to minimize the time taken to determine the quality of seed lots and arrange early marketing of superior seed lots or to store them for longer duration than regular seed lots.

(B)

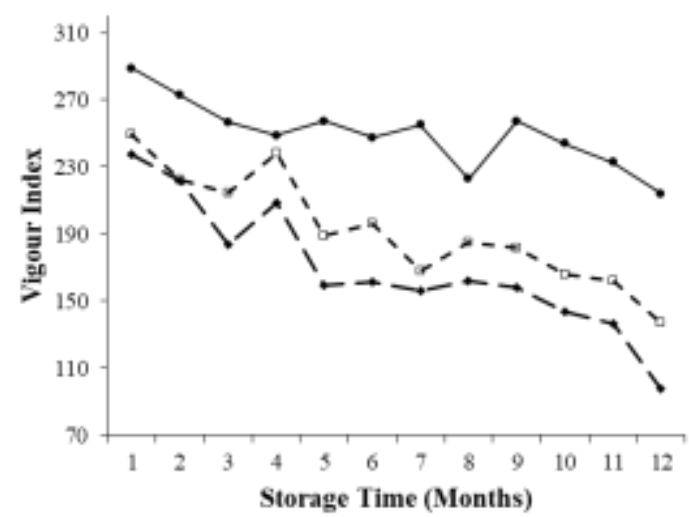

Fig. 2: Period of storage time and packing materials affected on vigour index of Tomato (A) Lanka Sour and (B) Ravi stored in low temperature condition (LT), Gannoruwa (MCWZ), Kundasale (MCIZ) and Mahallluppallama (LCDZ) over 12 months period. Means and SE \pm , at $\mathrm{p}=0.05$ level determined by LSD mean separation 
Table 3: Correlation between first count germination, final count germination, moisture, field emergence and vigour index of two tomato varieties over 12 months period.

\begin{tabular}{llccc}
\hline \multicolumn{1}{c}{$\begin{array}{c}\text { First-count } \\
\text { Germination }\end{array}$} & $\begin{array}{l}\text { Final-count } \\
\text { Germination }\end{array}$ & Moisture & $\begin{array}{l}\text { Field } \\
\text { emergence }\end{array}$ & $\begin{array}{c}\text { Vigour } \\
\text { index }\end{array}$ \\
\hline First-count Germination & $0.903 *$ & $-0.707 *$ & $0.598^{*}$ & $0.906^{*}$ \\
Final-count Germination & & $-0.679 *$ & $0.537^{*}$ & $0.805 *$ \\
Moisture & & & $-0.377^{*}$ & $-0.614^{*}$ \\
Field emergence & & & $0.662 *$ \\
Vigour index & & & \\
\hline statistically significant at $p=0.05$ & & &
\end{tabular}

\section{Detection of Clavibacter michiganensis subsp. Michiganensis (Cmmv) in Tomato Seeds.}

Clavibacter michiganensis is a causal organism for bacterial canker which is seed borne and considered as the most destructive bacterial disease of tomato (Sen et al., 2015). The biggest challenge of having this pathogen in seeds is that, the seeds might produce normal, symptomless healthylooking seedlings and the farmers will not notice the disease symptoms until 30-40 days after transplanting because of the long incubation period that the pathogen has (Chang et al, 1991). Samples taken from all storage conditions during the 1, 3, 6, 9 and 12 months in both varieties indicated positive results for Clavibacter michiganensis.

To diagnose the disease and for detecting Cmmv, the use of antiserum (Obata and Yamamoto, 1967), selective medium method (Shirakawa and Sasaki, 1988), enzyme-linked antibody method (Shirakawa and Sasaki, 1990), PCR methods (Dreier et al., 1995), DIBA method and TPI method (Ishii and Takemoto, 2001) have been previously reported, but these methods require equipment and many operations and considerable time for diagnosis and detection.

Therefore, in the present study, ImmunoStrip ${ }^{\mathrm{TM}} \mathrm{Cmmv}$ method was used as a simpler and more efficient method for diagnosing tomato canker disease which is commercially available and the diagnosis could be performed easily and in a short time (Tanina and Kawaguchi, 2011).

Sueno et al (2015) revealed from their study that $\mathrm{Cmmv}$ is capable of surviving in seeds for minimum 5 years under certain conditions. The level of seed infection did not affect the performance of seed germination undesirably when they used seeds immediately after harvest for their study. However, in the present study, germination percentage in the seeds stored in the controlled environmental conditions showed high in values throughout the one-year storage period.

In the present study, there is hardly any chance for the equilibrium moisture content in seeds to fluctuate, because the tomato seeds were packed and sealed in triple laminated aluminum foil. Before concluding the behavior of tomato varieties, future studies should focus on effect of pathogen viability and assessing factors of storage environment to growth of virulence and their survival. Moreover, this study revealed that fluctuating temperature and RH conditions affected seed germination and survival of pathogen in seeds stored in Gannoruwa, Kundasale and MahaIlluppallama throughout the one year storage period when initial qualities of seed lots were at acceptable level.

Reduced and delayed emergence of seedlings in the field have been resulted from weakened germination caused by the seed borne pathogens (Finch-Savage, 1995). Contamination of plants and seeds by diverse plant pathogens like bacteria, fungi or viruses in the field, during processing, packaging or storage tend to lose vigor. This could occur directly or indirectly by the depletion of enzymes and production of toxic substances and restricting the plant capability to yield the normal seed (Dornbos, 1995). When humidity and temperature are not controlled, they can strain the seed during storage and transport, and accelerate the deterioration by pathogenic infections (Hampton, 2000). Seed lots with significant amount of vigour were good enough to protest these stresses and tensions and maintain their germination power for longer periods. Vigour loses quickly by the poor storage condition and low vigour resulted reduction in germination of a seed lot which mainly rely on plant species and conditions on transportation and storage. Although, storages with controlled environmental conditions assist to maintain rate of vigour losing in considerably but not be prevented (Halmer \& Bewley, 1984). The present study confirms findings reported by the above authors.

\section{Detection of Tomato Spotted Wilt Virus (TSWV) in Tomato Seeds}

Tomato spotted wilt virus (TSWV) is a disease common in temperate, subtropical, and tropical regions around the world (Peters, 1998). It is a member of the Tospo virus genus and one of the major threats to tomato productivity (Gupta et al, 2020). Apart from the severe necrosis and mottling, this virus infects on the stems and leaves and also damages the fruits ultimately lowering the commercial value. Test results for TSWV in all samples from four different storage conditions in two varieties during the 1, 3, 6, 9, and 12 months were positive for the virus. So far, evidence on the transmittance of TSWV through seeds is not available.

\section{Detection of Leaf Curly Top Virus (LCTV) in Tomato}

None of the seedling samples gave positive results for LCTV. Therefore, the specific effect of this plant virus on seed quality parameters could not be assessed. 
Seeds that ensure good agronomic performance are vital for the success of a crop that must have genetic, physical, physiological qualities and free from diseases (Krzyzanowski et al., 2008). In the present study, although the seed lots had good initial germination and acceptable moisture content, germination and field emergence dropped drastically during storage. This type of drastic deterioration of physiological quality appears to be associated with several factors including health condition of the seed lot.

Behavior of a seed lot could be examined and assessed under different geo-ecological and controlled environmental conditions, and may provide a better understanding of their future performances under a wide range of environmental conditions. Results of the present study revealed that, storage temperature and moisture content are significant elements influencing quality parameters of tomato. First and final count germination, field emergence and vigour index differed among seed lots and favorable low temperature conditions led to the highest. However, germination and other quality parameters declined drastically in Gannoruwa, Kundasale and Mahallluppallama. The variances in field emergence were revealed that there were differences in seed lots. Unhealthy condition of the seed lots of both varieties influenced the vigour of the seed lots. Variety Ravi was more vulnerable to decrease in seed quality parameters when compared to variety Lanka Sour.

\section{Seed Protein and Carbohydrate (CHO) Content}

There were significant effects of storage period $(\mathrm{p}<0.0001)$, storage condition $(\mathrm{p}=0.0268)$, variety $(\mathrm{p}=0.0009)$ and interaction between storage time and storage condition $(\mathrm{P}<0.0001)$ on seed protein content. CHO content was affected by the storage time $(\mathrm{p}<0.0001)$ and storage condition $(\mathrm{p}=0.0043)$ only (Figure 3$)$.

Most seeds consist of Carbohydrates, proteins and lipids as the main reserves (Alencar, 2012). Of these compounds, some perform a protective role where water absorption and removing from seeds are taken care of. Water removal from the seed during the last stage of development is essential to survive under adverse environmental conditions for considerable time period (Kermode, 2011).

During seed maturation, Storage proteins are synthesized (Shewry et al., 1995) and first cleaved to peptides by particular end-proteinases and then hydrolyzed to free amino acids. These proteinases are available for the initial cleavage of the storage proteins of most species. However, synthesized proteinases during seed maturation, which are responsible in hydrolyzing the storage proteins, are persistent and dormant until germination in some species (Callis, 1995).

Various compounds from mother plant are transferred into the seeds in different quantities that indirectly influenced the seed germination (Donohue, 2009; Baskin and Baskin,
2014). For example, species such as tomatoes (Solanum lycopersicum) have a hard endosperm cell layer on their mature seeds, which is greatly weakened during seed germination (Nonogaki et al., 2000).

In the present study, protein content decreased over time in both varieties. There was no significant difference in protein content of seeds before and after processing. From processing up to third month, seed protein content decreased significantly under four storage environmental conditions except in variety Ravi at MahaIlluppallama. Moreover, protein content of both varieties decreased nonsignificantly under the four different environmental conditions after sixth months of the storage. Many studies have shown that there was a considerable correlation between TSWV infection and an increment of total amino acids and amides in both leaves and stems (Selman et al, 1961; Nachappa et al, 2013). According to Gupta et al, (2020) in his studies, TSWV inoculation decreased abundance of proteins involved in the tetrapyrrolle reaction and light reaction while glycolysis, TCA cycle, electron transport chain, and amino acid metabolism pathways were found to be upgraded. In the present study, protein content in variety Ravi showed small increment after third month in the storage at low temperature and at Gannoruwa, and in variety Lanka sour stored at Gannoruwa. Protein content decreased after third month at other storage conditions in both varieties. This may be due to the effect of infected TWSP in the mother plants of tomato. Germination percentage also decreased drastically in variety Ravi compared to variety Lanka Sour. A significant correlation was observed in protein content and seed germination (0.3855. $p<0.0001)$. High temperature treatment or heat shocks of eukaryotic and prokaryotic cells increase their capacity of degradation (Callis, 1995). Several m-RNA, which encodes proteins with amino acid identity, is known for protease expression when tissue is exposed to various environmental stresses (Guerrero et al., 1990). Such variations of protein content of seeds observed in the present study may be due to such kind of accumulation made by the stress of Clavibacter michiganensis and TSWV.

Carbohydrate content was also increased significantly up to third month and decreased again up to six months. From 6month onwards, $\mathrm{CHO}$ content increased significantly again except in seeds stored at low temperature condition in both varieties.

increasing glucose level during the germination process could assist the signaling of abscisic acid (ABA) that leads to degrade starch and delaying germination in tomato (Bradford et al., 2003) and Arabidopsis (Xing et al., 2009). Seeds stored for a longer period, demonstrated a significant decrease in starch and soluble proteins in Jatropha curcas seeds without infections of any pathogens. Moreover, high concentration of reducing sugars promotes the 
glycosylation of proteins and lipid peroxidation. This process led to outflow high concentration of electrolytes and consequently affect the embryo damage extensively or deterioration (Escandon et al., 2013).

It is clearly visible that perusal data that the compositional changes in tomato seeds could occur during storage. Total

(a)

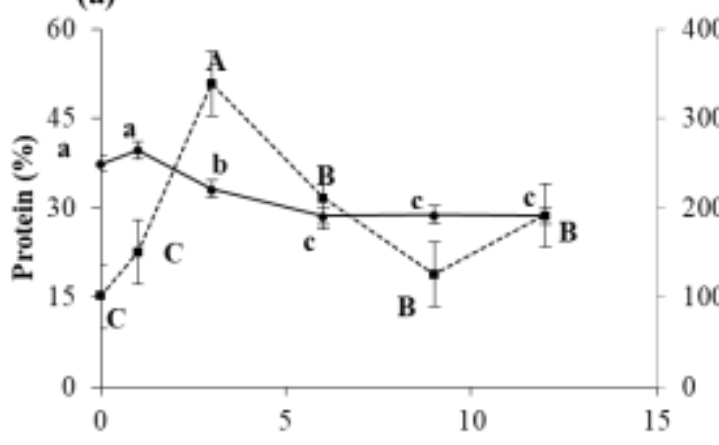

(b)

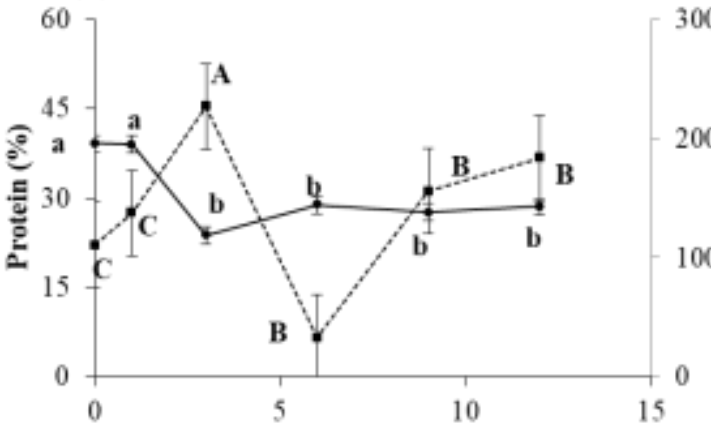

(c)

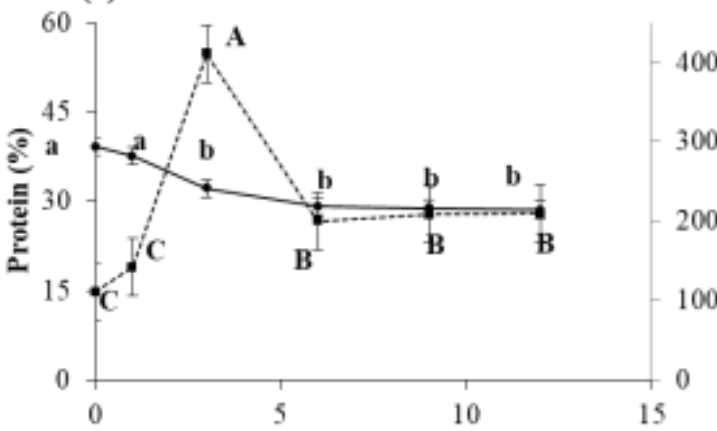

(d)

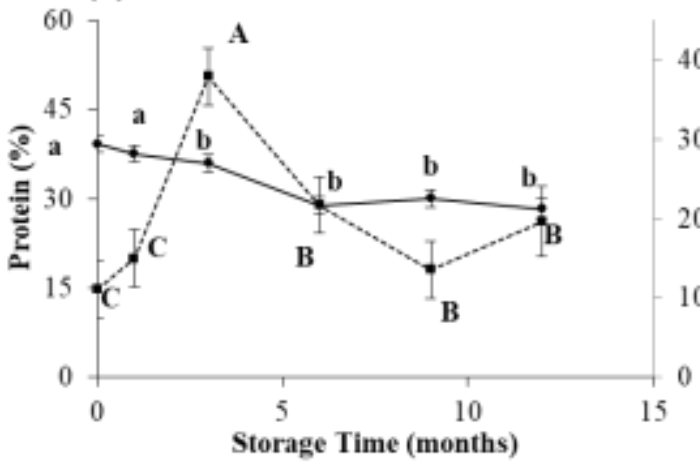

soluble sugar, reducing sugar and sucrose amount were decreased and it affected the tomato seed viability and vigour of the seedling (Sharma et al., 2007). Despite these studies, the understanding of the relationship between primary seed metabolism and germination is still not worthy (Nonogaki et al., 2010).

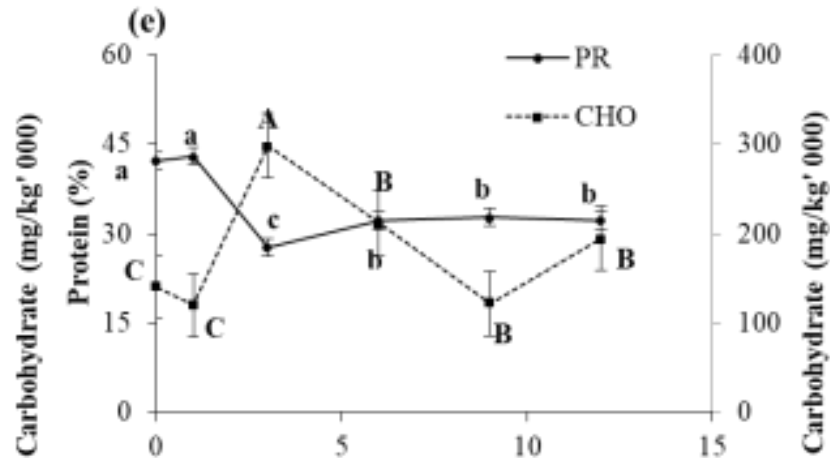

(f)

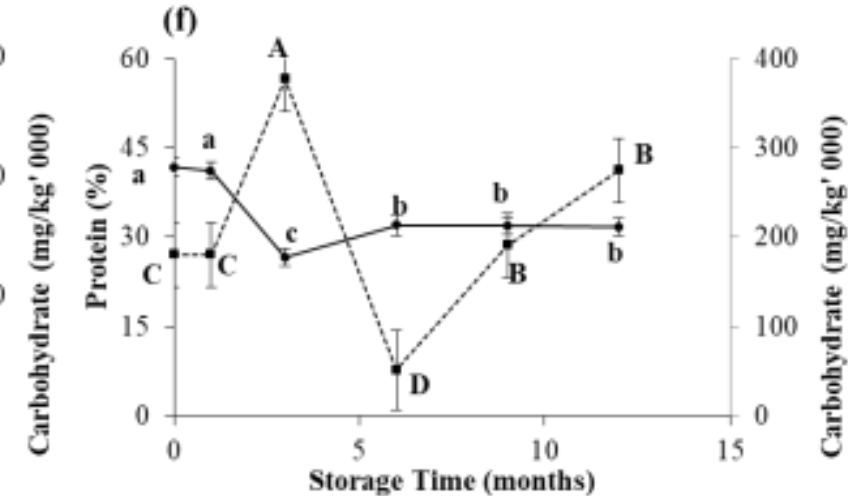

100

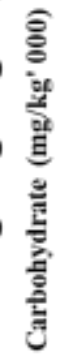

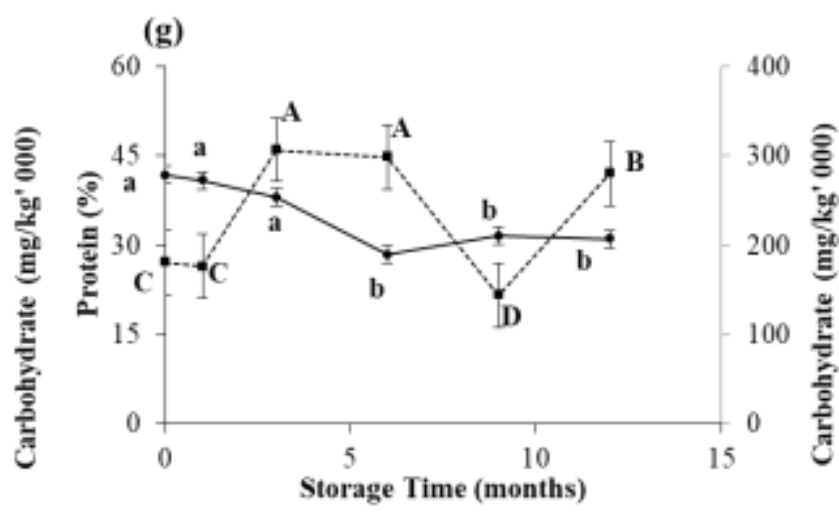

Fig. 3: Effect of storage condition and storage time on protein and CHO content in variety Lanka Sour (a,b,c,d) and Ravi $(\mathrm{e}, \mathrm{f}, \mathrm{g})$ at four different storage conditions with storage time. a and e: Low temperature condition (LT); $\mathrm{b}$ and $\mathrm{f}$ : Gannoruwa (MCWZ); c: Kundasale (MCIZ); d and g: MahaIlluppallama (LCDZ). Different upper case and lower-case letters within a $\mathrm{CHO}$ and protein show significant difference at $\mathrm{p}=0.05$ level determined by LSD mean separation 


\section{Conclusion}

The regular laboratory germination test for tomato seeds is inadequate to verify the field emergence potential. However, the first count during the germination test at seven days was a good indicator of field emergence and significantly correlated with it. Low, constant temperature and RH conditions were the most suitable for storage of tomato seeds at least for 12 months when packed in triple laminated aluminum foil. Even though initial seed quality is good, assuring seeds free from diseases is a must for prolong storage. Seed germination does not represent the potential field emergency. Physiological changes that occur in seeds due to temperature, $\mathrm{RH}$, changes in proteins and carbohydrate content, CMMV and TSWV contamination during storage were found be the causal factors for reduction in seed germination, field emergence and vigour index.

Clavibacter michiganensis subsp. Michiganensis was found in all test samples and this seed borne pathogen could spread through seed to new cultivations. This knowledge is very much important to prevent releasing unhealthy seed lots to farmers and therefore, the seed health test may be implemented as a mandatory test for tomato.

\section{Authors' Contribution}

Formal analysis, R.A.I.S.A.; Funding acquisition, R.A.I.S.A.; Designing and planning, R.A.I.S.A., S.L.W. and C.K.B.; Administration, S.L.W. and C.K.B.; Resources, R.A.I.S.A. and C.K.B.; Supervision, S.L.W. and C.K.B.; validation, C.K.B.; visualization, R.A.I.S.A. and C.K.B.; writing-original draft, R.A.I.S.A.; review and editing, S.L.W. and C.K.B. Final form of manuscript is approved by all authors.

\section{Conflict of Interest}

The authors declare that there is no conflict of interest with present publication appreciated.

\section{Acknowledgements}

Authors wish to acknowledge Prof. L. D. B. Suriyagoda of the Department of Crop Science, Faculty of Agriculture, University of Peradeniya for the guidance in statistical analysis and the staff of seed health testing unit of the Seed Certification Service, DOA for pathogenic assesses.

\section{References}

Abdul-Baki AA and Anderson JD (1973) Vigour determination of Soybean seeds by multiple criteria. Crop Science 13: 630. DOI: $10.2135 /$ cropsci1973.0011183X001300060013X

Adriana L, Tassi W, Santos JFD and Panizzi RDC (2012) Seedborne pathogens and electrical conductivity of soyabean seeds. Scientia Agricola 69:19-25. Doi: 10.1590/S0103$\underline{90162012000100004}$

Adsul AT, Vivek CP and Deshmukh MP (2018) Inheritance of seed longevity and its association with other seed-related traits in Soybean (Glycine max). Agricultural Research 7:105-111. DOI: $10.1007 / \mathrm{s} 40003-018-0297-7$

Alencer NM, Innecco R, Gomes-Filho E, Gallao MI, Alvarezpizarro JC, Prisco JT and De Oliveira AB (2012) Seed reserve composition and mobilization during germination and early seedling establishments of Cereus jamacaru D.C. ssp.jamacaru (cactaceae) An Acad.Bras.Cienc 84(3): 823832. DOI: $10.1590 / 5001-37652012000300024$

Ariyarathna RAIS, Weerasena SL and Beneragama CK (2020) Sustenance of Seed Germination Potential of Two Okra (Abelmoschus esculentus L. Moench) Varieties under Different Environmental Conditions in Sri Lanka. Tropical Agricultural Research 31(1): 21-30. DOI: 10.4038/tar.v31i1.8341

Ariyarathna RAIS, Weerasena SL and Beneragama CK (2020a) Quality Deterioration of Commercial Bean (Phaseolus vulgaris) Seeds Stored under Contrasting Environmental Conditions in Sri Lanka. International Journal of Applied Science and Biotechnology 8(1): 33-44. DOI: $\underline{\text { 10.3126/ijasbt.v8i1.28253 }}$

Arrieta-Baez D, Cruz-Carrillo M, Garcia, Cipriano, ArmentaBojorquez, Adolfo, Montoya JE and Jaramillo-Flores M (2015) Production and Handling of Tomato with High Nutrition Quality: In Production and Handling of Tomato with High Nutrition Quality, Eds: Yiu Hin Hui, E. Özgül Evranuz, Handbook of Vegetable Preservation and Processing. pp. 629-648. CRC PressTaylor \& Francis Group, Editors. DOI: 10.1201/b19252-30

Barros ASR and Marcos-Filho J (1997) Tests for rapid evaluation of soybean seed vigor. Brazilian Journal of Seeds 19(2): 288-294. (Translated to English)

Baskin CC and Baskin JM (2014) Seeds: Ecology, Biogeography and Evolution of Dormancy and Germination. $2^{\text {nd }}$ edition. San.Diego.CA; Elsvier. Available at: https://www.researchgate.net/publication/291850436_See d_Ecology_Biogeography_and_Evolution_of_ Dormancy_and_Germination

Bergougnoux V (2014) The history of tomato: From domestication to bio pharming. Biotechnology Advances 32(1): 170-189. DOI: 10.1016/j.biotechadv.2013.11.003

Bradford KJ, Downie AB, Gee OH, Alvarado V, Yang H and Dahal P (2003) Abscisic acid and gibberellin differentially regulate expression of genes of the SNF1-related kinase complex in tomato seeds. Plant Physiology 132:1560-76. Doi: $10.1104 / \mathrm{pp} .102 .019141$

Callis J (1995) Regulation of protein degradation. The plant cell 7:845-857. Doi: $\underline{10.2307 / 3870041}$

Chang RJ, Ries SM and Pataky JK (1991) Dissemination of Clavibacter michiganensis subsp. michiganensis by Practices Used to Produce Tomato Transplants. Phytopathology 81:1276-1281. DOI: 10.1094/Phyto-81$\underline{1276}$

Copeland LO and McDonald MB (eds) (1995) Principals of Seed Science and Technology. Third edition. Chapman and Hall, 181-220. 
Donohue K (2009) Completing the cycle; material effect as the missing link in plant life histories. Philosophical. Transaction of the .Royal Society B: Biological Science 364:1059-1074. DOI: $10.1098 /$ rstb.2008.0291

Dornbos DL Jr (1995) Production environment and seed quality. In Seed quality-basic mechanisms and agricultural implications, ed. A.S. Basra, 119-152. New York: Food Products Press. DOI: $10.4324 / 9781003075226-4$

Dreier J, Bermpohl A and Eichenlaub R (1995) Southern hybridization and PCR for specific detection of phytopathogenic Clavibacter michiganensis subsp. Michiganensis. Phytopathology 85: 462-468. DOI: 10.1094/Phyto-85-462

Dutt M and Geneve R (2007) Time to Radicle Protrusion Does Not Correlate with Early Seedling Growth in Individual Seeds of Impatiens and Petunia. Journal of the American Society for Horticultural Science 132: 423-428. DOI: $\underline{10.21273 / J A S H S .132 .3 .423}$

Dutta A and Dutta G (2016) Comparing Optimum Barrier Variables of Aluminium and MPET Foil Based Laminates for Coffee Packaging. Journal of Applied Packaging Research 8 (3): 52-60. DOI: 10.14448/japr.08.0019

Escandon JM, Silva BCF, Silva SRS, Granja JAA, Alves MCJC, and Pomeplli MF (2012) Germination responses of Jatropha curcas L. seeds to storage and aging. Industrial crops and products 44: 684-690. DOI: $\underline{10.1016 / j . i n d c r o p .2012 .08 .035}$

FAO: Seed and seed quality: Technical information for FAO emergency staff (2016) [Online] [Access on 2019.08.10] available http://www.fao.org/fileadmin/templates/tc/tce/pdf/Appen dix_14_Seed_and_Seed_Quality_for_Emg.pdf

Ferrari AA, Fernandes EADN, Tagliaferro FS, Bacchi MA and Martins TCG (2008) Chemical composition of tomato seeds affected by conventional and organic production systems. Journal of Radio analytical and Nuclear Chemistry 278: 399-402. DOI: 10.1007/s10967-008$\underline{0808-2}$

Finch-Savage WE (1995) Influence of seed quality on crop establishment, growth, and yield, in Seed Quality (ed. A.S. Basra), pp: 361-384. Food Products Press, New York.

Gholami S, Sharafi S, Ghasemi A and Pinto S (2009) Bean seed reserve utilization and seedling growth as affected by seed size, salinity and drought stress. Journal of Food Agriculture and Environment 7: 411-414. Available at: http://www.isfae.org/scientificjourna

Guerrero FD, Jones JT and Mullet JE (1990) Turgor-responsive gene transcription and RNA levels increase rapidly when pea shoots are wilted. Plant Molecular Biology 15:11-26.

Gupta R, Min CW, Kim SW, Yoo JS, Moon AR, Shin AY, Kwon SY and Kim ST (2020) A TMT-Based Quantitative Proteome Analysis to Elucidate the TSWV Induced signaling cascade in Susceptible and Resistant Cultivars of Solanum lycopersicum. Plants 9: 1-15 available at: https://www.mdpi.com/journal/plants.
Halmer P and Bewley JD (1984) A physiological perspective on seed vigour testing. Seed Science and Technology 12:561575 .

Hampton J (2000) Seed vigour: Its importance and application. New Zealand Seed Technology. [Access 2020.05.04] available http://www.semec.ws/semec/seedvigourintroduction.htm/

Ishii DT and Takemoto H (2001) Detection of the tomato blast fungus Clavibacter michiganensis subsp. Michiganensis by Dot Immuno-binding assay (DIBA) method and Tissue printing Immunoassay (TPI) method. Fukuoka Agricultural Research Report 20: 42-47.

ISTA (2015) International Rules for Seed Testing vol. 2015 introduction i-9A4

Kermode AR (2011) Plant storage products. (Carbohydrate, oils and proteins). [Online] [Access on 2019310.10] available at : onlinelibrary.wiley.com/ DOI: 10.1002/9780470015902.a0001325.pub2

Krzyzanowski FC, France NJB, Henning AA and Costa NP (2008) Soybean seed as a technology and basis for high yields seed series. Londrina: Embraa. (Translated to English)

Maity A and Pramanik P (2013) Climatic change and seed quality; an alarming issue in crop husbandry. Current Science 105 (10):1336-1338

Nachappa P, Margolies D, Nechols J, Whitfield A and Rotenberg D (2013) Tomato Spotted Wilt Virus Benefits a NonVector Arthropod, Tetranychus Urticae, by Modulating Different Plant Responses in Tomato. PLOS ONE. 8. e75909. DOI: $10.1371 /$ journal.pone.0075909

Nonogaki H, Bassel GW and Bewley JD (2010) Germination still a mystery. Plant Science 179: 574-581. DOI: 10.1016/j.plant sci.2010.02.010

Nonogaki H, Gee OH and Bradford KJ (2000) A GerminationSpecific Endo- $\beta$-Mannanase Gene is expressed in the Micropylar Endosperm Cap of Tomato Seeds. Plant Physiology 123:1235-1246. DOI: 10.1104/pp.123.4.1235

Oakley K, Kester S and Geneve R (2004) Computer-aided digital image analysis of seedling size and growth rate for assessing seed vigour in impatiens. Seed Science and Technology 32:837-845. DOI: 10.15258/sst.2004.32.3.18

Obata T and Yamamoto Y (1967) Diagnosis of tomato ulcer disease by antiserum. Kanto Disease Research Institute, 14: 39 .

Peters DI (1998) An updated list of plant species susceptible to tospo viruses. In: Fourth International Symposium on Tospovirus and Thrips in Floral and Vegetable Crops. Eds. D. Peters and R. Goldbach, 10-110. Wageningen, the Netherlands

Pinto TLF, Cicero SM and Forti VA (2007) Avaliação de danos por umidade, em sementes de soja, utilizando a técnica da análise de imagens. Image analysis technique to evaluate weathering damage in soybean seeds) Revista Brasileira de Sementes 29(3): 31-38.(translated to English) 
Pradhan BK and Hemant KB (2012) Effect of Storage Conditions and Storage Periods on Seed Germination in Eleven Populations of Swertia Chirayita: A Critically Endangered Medicinal Herb in Himalaya.The Scientific World Journal 2012:1-9 DOI: 10.1100/2012/128105

Punyawardhana BVR (2008) Rainfall and Agro ecological zones of Sri Lanka (Sinhala): 31-40.

Ranst EV, Verloo M, Demeyer A and Pauwels JM (1999) Manual for the Soil Chemistry and Fertility Laboratory-Analytical Methods for Soils and Plants, Equipment, and Management of Consumables pp.243. NUGI 835, Ghent, Belgium (ISBN 90-76603-01-4)

Roberts EH and Ellis RH (1989). Water and seed survival. Annals of Botany. 63(1): 39-52. DOI: 10.1093/oxfordjournals.aob.a087727

Robertson GL (2013) Food packaging principals and practice. pp: 5-26 Third edition, CRC press, Taylor and Francis Group, New yolk

Sano N, Rajjou L, North HM. Debeaujon I, Marion-Poll A and Seo M (2016) Staying Alive: Molecular Aspects of Seed Longevity. Plant and Cell Physiology 57(4): 660-674. DOI: $10.1093 / \mathrm{pcp} / \mathrm{pcv} 186$

Santorum M, Nóbrega LHP, Godoy de Souza1 E, Diego dos Santos, Boller W and Mauli (2013) Comparison of test for the analysis of vigor and viability in soybean seeds and their relationship to field emergence. Acta Scien-tiarum, Maringá 35(1): 83-92. DOI: $\underline{10.4025 / \text { actasciagron.v35i1.14955 }}$

Seed Certification Standards Hand book part II, Seed rules and crops, Sri Lanka. (1983).pp 3-1

Selman IW, Brierley MR, Pegg GF and Hill TA (1961) Changes in the free amino acids and amides in tomato plants inoculated with tomato spotted wilt virus. Annals of applied biology 99: 601-605. DOI: 10.1111/j.17447348.1961.tb03657.x

Sen Y, derWolf J, Visser RGF and Heusden AWV (2015) Bacterial Canker of Tomato: Current Knowledge of Detection, Management, Resistance, and Interactions. Plant Disease 99:4-13. DOI: 10.1094/PDIS-05-14-0499FE

Shaban M (2013) Study on some aspects on seed viability and vigour. International journal of Advanced Biological and Biochemical Research 1(12): 1692-1693. [online] available at http://www.ijabbr.com [accessed on10.06.2019]

Sharma S, Gambhir S and Munshi SK (2007) Changes in Lipid and Carbohydrate Composition of Germinating Soybean Seeds under Different Storage Conditions. Asian Journal

$\begin{array}{lclll}\text { of Plant Sciences } & \text { 6: } & \text { 502-507. } & \text { DOI: } \\ \text { 10.3923/ajps.2007.502.507 } & & & \end{array}$

Shelar VR, Shaikh RS and Nikam AS (2008) Soybean seed quality during storage: A review. Agricultural Reviews 29:125131.

Shewry PR, Napier JA and Tatham AS (1995) Seed storage proteins: Structures and biosynthesis Plant Cell 7: 945956.

https://www.arccjournals.com/uploads/articles/ar292006. pdf.

Shirakawa T and Sasaki T (1988) Selection medium for detection of tomato canker bacterium. Nikkatsu Shiho 54: 540-543. DOI: $\underline{10.3186 / j j p h y t o p a t h .54 .540}$

Shirakawa T and Sasaki T (1990) Detection of the tomato canker bacterium Clavibacter michiganensis subsp. Michiganensis by enzyme-linked antibody method. Vegetable and Tea Experiment Station Research Report C1: 75-83.

Solarte ME, Melgarejo LM, Martínez O, Hernández MS and Fernández-Trujillo JP (2014) Fruit quality during ripening of Colombian guava (Psidium guajava L.) grown at different altitudes. Journal of Food Agriculture and Environment 12: 669-675.

Statistical abstract, Department of Census and Statics Sri Lanka (2018) [online] [Access on 2018.08.15] http://www.statistics.gov.lk/Abstract2018/index.asp?page $=$ chap 1

Statistical abstract, Department of Statics, Sri Lanka. (2019) [online] [Access on 2019.08.15] http://www.statistics.gov.lk/Abstract2018/index.asp?page $=$ chap 1

Sueno WSK, Alvarez AM and Ingram DM (2015) Bacterial canker: Impact on seed borne inoculum on plant infection in green house tomatoes. Acta Horticulture 1069: 301308. DOI: $10.17660 /$ ActaHortic.2015.1069.43

Tanina K and Kawaguchi A (2011) Simplified method to isolate Clavibacter michiaganensis sub spp. Michiganensis using ImmunoStrip TMCmm. Japanese Journal of Phytopathology 77(4): 287-290. DOI: 10.3186/jjphytopath.77.287

Vertucci C and Roos E (1993) Theoretical basis of protocols for seed storage II: The influence of temperature on optimal moisture levels. Seed Science Research 3(3): 201-213. DOI: $10.1017 / \mathrm{S} 0960258500001793$

Xing Y, Jia W and Zhang J (2009) AtMKK1 and AtMPK6 are involved in abscisic acid and sugar signaling in Arabidopsis seed germination. Plant Molecular Biology 70(6):725-736. DOI: $\underline{10.1007 / \mathrm{s} 11103-009-9503-0}$ 